Mary S. Townsend-assistant reference librarian-Franklin and Marshald. College library, Lancaster, Pennsylvania.

Karin Trainer-descriptive cataloger-

Princeton University library, New Jersey.

Karen S. Wedde-lower division librarian -University of OKLahoma libraries, Norman.

TaWANA P. West-instructor-Texas A\&M UnIVEnsity library, College Station.

BonNie L. WeTzel-assistant catalog librarian-New Mexico State University, Las Cruces.

Claire B. Whittaken-original cataloger for English language-UNIVERSITY of VirgINIA, Charlottesville.

Theresa S. Wiggins-psychology librarian -Panceton Univensity library, New Jersey.

Edna J. Williams-assistant reference librarian-FLORIDA INTERNATIONAL UNIVERSITY, Miami.

DOROTHY WINTER-serials librarian-UNIversity of Nevada, Las Vegas.

\section{Classified Advertising}

NOTICE
Respondents to advertisers offering faculty
"rank" and "status" are advised that these terms
are ambiguous and should inquire as to benefits
involved.
All advertisements submitfed by instifutions
offering positions must include a salary range.
The range should provide the applicant with an
indication of the salary the institution is willing
to provide for the position offered.
All advertisements lor the Positions Wanted
and the Positions Open classifications will be ed-
ited to exclude direct or indirect references to
race, creed, color, age, and sex as conditions of
employment.

\section{POSITIONS WANTED}

SPECIAL COLLECTIONS/MANUSCRIPTS/RARE BOOKS. Seeking responsible administrative position in forward looking college/university, or other repository, where the need for enlightened and modern preservation measures and managerial techniques has been recognized, and the commitment made to implement them. BA, MA, English; MA, Library Science, University of Chicago, Law school. Continuing education in conservation of research library materials. 7 years' experience. Currently employed by major Eastern small university. Write Box $834, C R L, 50 \mathrm{E}$. Huron St., Chicago, IL 606II.

FOR SALE

INTERNATIONAL (METRIC) SYSTEM! Names, symbols, "Iwo-way" conversion factors for all physical units. Inexpensive, most up-to-date booklet for your ready relerence needs. \$2. Kulchar Studio, Box 1992.C. Philadelphia, PA 19105

\section{POSITIONS OPEN}

Administration

ASSISTANT HEAD, Department of rare books and special collections. Responsible for continuous series of
S. Francis Woods-assistant curator of visual collections, Fine Arts Library-Harvard University, Cambridge, Massachusetts.

Elaine H. Woodward-serials catalogerUnIVERSITy OF VIRGINIA, Charlottesville.

Daniel Wren-curator, Bass (American business history) Collection-UNIVERSITY of OKLAHOMA, Norman.

\section{RET IREMENTS}

Charles M. Adams, director of the Sinclair Library at the UNIVERSITY of HAWAII, retired recently after four years of service.

Fritz Veit, director of libraries, Chicago State University, retired on August 31 after serving nearly twenty-five years in this position.

Katherine WalKer, associate director of the university libraries at NoRThERN ILLINOIS UNIvERSITY, retired on August 31 after completing thirty-one years of service.

exhibitions and for organizing nonbook materials. Takes part in bibliographic searching, reference work, and special projects. Aids in the selection of new materials. $M L S$ graduate degree in the humanities. Reading knowledge of Latin. French and German. 5 years of progressively advanced professional library experience, at least 2 in rare book field. Salary $\$ 12,804$. Write to Mrs. Doris $H$. Asher, Asst. for Pers. and Staff Development, Univ. of Michigan Library, Ann Arbor, MI 48104. A' nondiscriminatory, affirmative action employer.

DIRECTOR OF LIBRARIES. Position available now. Can didate must possess MLS degree from ALA-accredited program and proven ability in a college or university library on the assistant level or up. Director is responsible for operation of the central library and two branches with $100 \mathrm{FTE}, 400,000$ volumes serving ||,000 students

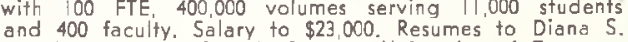
Nafalcio, Chrm., Search Comm., University of Texas at E) Paso, El Paso, TX 79968. An equal opportunity/affirmative action employer.

DIRECTOR OF ACADEMIC SERVICES. To coordinate/ administer Library and Instructional Resources (program development equipment, ufilization, and all production, development, equipment, ufilization, and all production, including TV), and to supervise staffs totaling 94. center currently independently operated, completed in 1968, serve student body of 11,000 and 600 faculty. 4-year liberal arts college with strong urban commitment. Metropolitan area offers both cultural and educational opportunities. Recruitment at $\$ 23,600$ with excellent fringe benefits. Doctorate and administrative experience in library and/or media preferred. We are an equal opportunity/affirmative action emplayer. Contact Dr. Donald Schwartz, Vice Pres. for Academic Affairs, University College at Buffalo, 1300 Elmwood Ave. Buffalo, NY $\mid 4222$.

HEAD OF TECHNICAL SERVICES AND PUBLIC SERYICES DIVISIONS. Each requires extensive experience in pro. gressively responsible positions. Salary range $\$ 14,000$. $\$ 16,000$. Write Joseph Jeffs, Univ. Ln., Georgetown University, 37 and 0 Sts. NW. Washington, DC 20007.

ASSISTANT DIRECTOR FOR TECHNICAL SERVICES, lOWA State University Library. A new administrative position to coordinate cataloging, bibliographic search, order, serials and binding. Reguirements: MLS 7 years of professional experience, with at least 4 years in technical services in a research library; emphasis on creativity in processing areas and proven administrative ability. Library collection of 960,000 volumes; a total budget above $\$ 2.500,000154$ appointive staff: campus community of 25000 . Faculty rank. TIAA excellent group medical and life insurance, month vacation per fiscal year. Available Summer 1974. Salary $\$ 16,000$ up, depending on 
qualifications, lowa State is an equal opportunity/affirmative action employer. Please apply by February 1 to Warren B. Kuhn Dean of LS, lowa State University Library, Ames, IA 50010.

ASSISTANT UNIYERSITY LIBRARIAN-Technical Services. We are seeking a prolessional librarian to fill an imministrative responsibility for the four technical services departments: accuisitions, serials, catalog and loan. The departments: acquisitions, serials, catalog and 17 professional lifour departments are comprised of 17 professional librarians + more than 60 FTE of clerical and other support of professional library experience in technical services operations in an academic library at least half of such experience in a supervisory or administrative capacity. Professional librarians at the Univ. of Arizona have faculty status, but 12-month contracts with 24 days per year of vacation, 12 days of sick leave, and a standard package of academic holidays and other fringe benefits. The minimum salary for this position is $\$ 16,000$ per year with some upward flexibility to account for length and type of experience as well as special academic training or other background. Send inquiries and resumes to W. David Laird, Univ. Ln., University of Arizona, Tucson, $A Z$ 85721. Applications will not be accepted after February I 1974. An equal opportunity employer.

\section{Cataloging}

SCIENCE CATALOGING LIBRARIAN with an MLS from an accredited library school. If math, geology, chem istry, physics or engineering was your area of study before obtaining your MLS, there might be employment for you at the University of Utah libraries. Salary: \$8.500: faculty rank as instructor: TIAA/CREF or Utah State Retirement lully funded by the University adds $10 \%$ to the salary. No experience necessary. An equal opportunity employer. Please send resumes beiore January 5, include 3 references. Write Winnifred Margetts Lib. Pers. Ofir., Marriott Library, University of Utah, Salt Lake City, UT 84112.

HEAD CATALOGER. MLS with considerable cataloging and administrative experience in major academic or research libraries. Department of 28 , including librarian catalogers. LC classification, OCLC participation. Working knowledge of French and German; other languages highly desirable. Salary $\$ 17,000$. Position available imme diately. Send resume to Director of Libraries, State I3901. An equal opportunity/affirmative action employer.
ing

\section{Reference}

REFERENCE SERVICES HEAD in large academic library system. Responsible for administration and coordination of relerence services, selection policy and staff develop ment in central reference collection. Also coordinate these functions with 14 departmental libraries, Qualifications: Master's in LS from ALA-accredited school minimum 5 years' academic reference experience. Mus have ability to innovate, initiate, and work elfectively with others. Minimum salary $\$ 12,000 /$ year, but commensurate with qualifications and experience. Submit resumes by February 15, 1974 to Admn. Asst. Univ of resumes by February 15, 1974 to Admn, Asst., Univ. of
Southern Calif. Library, Libn. Olf., University Park, Los Angeles, CA 90007 . An equal opportunity employer.

Serials

SERIALS DEPARTMENT HEAD. Minimum of 4 years' ex perience in serials, including serials cataloging. Ad ministrative experience desirable. Staff of 2 librarians II library assistants and some part-time help. Depart ment provides order and precatalog information ceives and records current periodicals and catalog's al serials. Salary $\$ 12,000$ per annum minimum. 35-hour work week, 22 working days vacation. Apply with vitae to $\mathrm{Mr}$. H. J. Skynner, Assoc, dir. for Tech Servs. Elizabeth Dafoe Librarv. University of Manitoba. Winnipeg, Mani. loba Canada.

SERIALS DEPARTMENT HEAD, lowa State University Library, to direct work of 4 prolessionais and 15 classiieu staff members in department presently receiving 14,500 titles. Departmental activities include both binding and gifts and exchange sections. Qualifications: MLS, 4 years related professional experience in search libraries, with 2 years of serials work very desirable demonstrated administrative ability and facility in working well with a large staff. Position and facility
Minimum salary $\$ 12,000$. Faculty rank, TIAA, month vacation per fiscal year, other excellent fringe benefits. lowa State is an equal opportunity/affirmative action employer. Please apply by February I to Warren B. Kuhn. Dean of LS, lowa State University Library, Ames, IA 50010

SERIALS LIBRARIAN, experienced, to organize and prepare for automation the serials functions in a new academic library. This person will be responsible for the acquisition, control and cataloging of serials. The position requires $M L S$ degree and at least one year experience with serials. Experience with automation aiso desirable. Minimum salary $\$ 9,500$ for 12 months. Contact Dr. Michael F. Kelly. Dir. of Ls., University of Texas at San Antonjo, 4242 Piedras Dr. E. San Antonio. TX 78284

Subject Specialists

SCIENCE RESEARCH LIBRARIAN Position open imme. diately in a state university. MLS knowledge of information needs of laculty and students in 5 engineering fields, geology, mathematics and physics, awareness of library applications of scientific and technical retrieval system required. Second master's degree helpful. Salary up to $\$ 11,000$ depending on qualifications. Excellent fringe benelits, faculiy rank, and eligibility for tenure. Apply to Pauline Franks, Assoc. Univ. Ln., University of Akron, Akron, OH 44325. An equal opportunity employer.

PHYSICAL AND ENGINEERING SCIENCES SPECIALIST. Responsible for assisting readers in the use of the library and its resources: selecting materials for the reference collection: compiling lists, research guides. bibliographies; maintaining contact with teaching and research staff. Qualifications: MLS from an ALA-accredited library school: BS in a physical or engineering science, and one or more years professional experience. Faculty status, liberal fringe benefits starting salary $\$ 10,296$ for calendar year. Affirmative action/equal opGeorlunity employer. Available immediately. Apply to Kingston, R! 0288!.

UNIVERSITY ARCHIVIST, management of university archives. Opportunity to expand collections, services and hire new support staff. Establish policies/procedures for collection, recording, organization, preservation, and use of university produced materials. Establish contacts with all university departments, organizations, current and retired faculty for intensive acquisition of material. Qualifications: MLS from accradited library school preferred or advanced degree in relevant field. Certificate 3 years" relevant archival experience required. Salary range: $\$ 11,500-\$ 13,000$. Send resume to Robert Ireland, Northwestern University Library, Evanston, IL 60201. An equal opportunity employer.

FACULTY VACANCY: With background in any one or more of the following areas-special library service or public library service or information science. Minimum beginning salary $\$ 13,000$ plus $2 / 9$ ths for summer session teaching. Prefer doctorate recipient or candidate and library and teaching experience. Small classes, congenial laculty. Interviews at ALA Midwinter. For affirmative information on lowa read "In the Sticks." Harpers October 1971. Write Frederick Wezeman, Dir., School of Lib. Sci., Univ. of lowa, lowa City, lowa 52242 (319) 353-3644; TWX 910-525-1391

HUMANITIES RESEARCH LIBRARIAN Position open im mediately in a state university. MLS knowledge of both English and foreign languages and literature philosophy and psychology required. Second master's degree help ful. Salary up to $\$ 11,000$ depending on qualifications. Excellent fringe benefits, laculty rank, and eligibility for tenure. Apply to Pauline Franks, Assoc. Univ. University of Akron, Akron, OH 44325. An equal oppor. tunity employer.

\footnotetext{
Serving libraries for over 25 years for

Building Programs-Reviews of Plans-

Equipment Layouts and Designs LIBRARY MANAGEMENT and
BUILDING CONSULTANTS, INC.

Box 58, Evanston, Illinois 60204 $312 / 446 / 8862$

Send for free brochures
} 

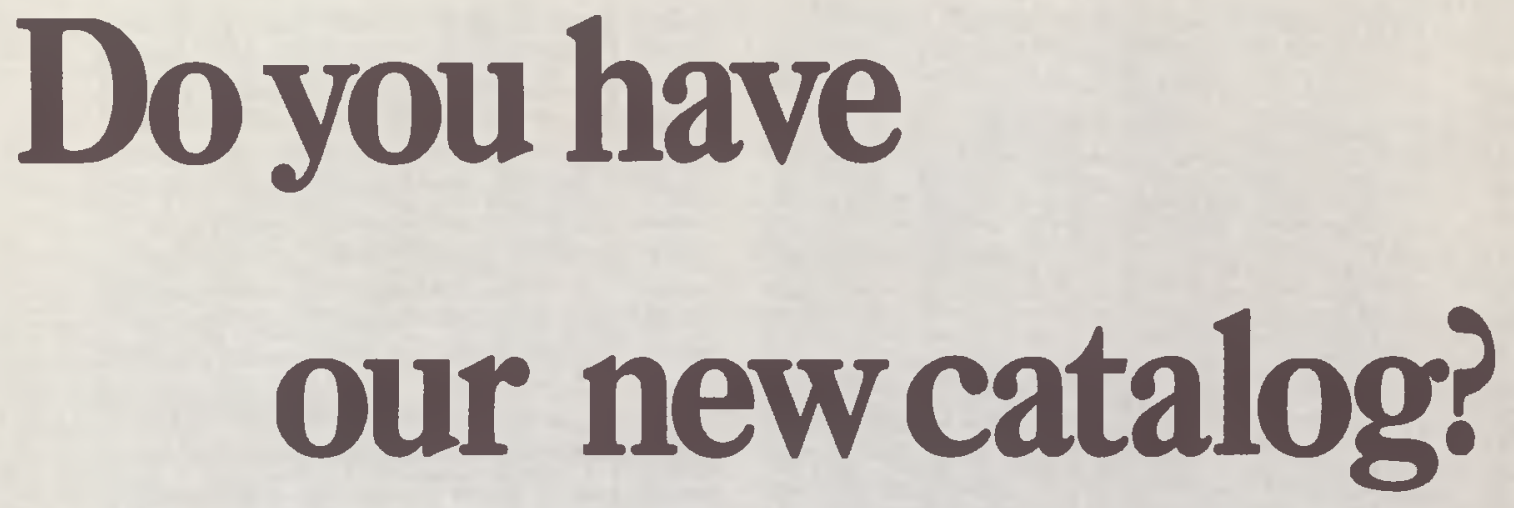

Write for one!

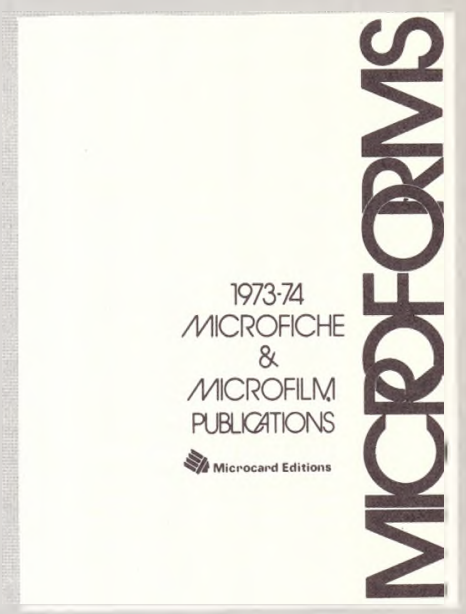

Microcard Editions

An Indian Head Company

A Division of Information Handling Services

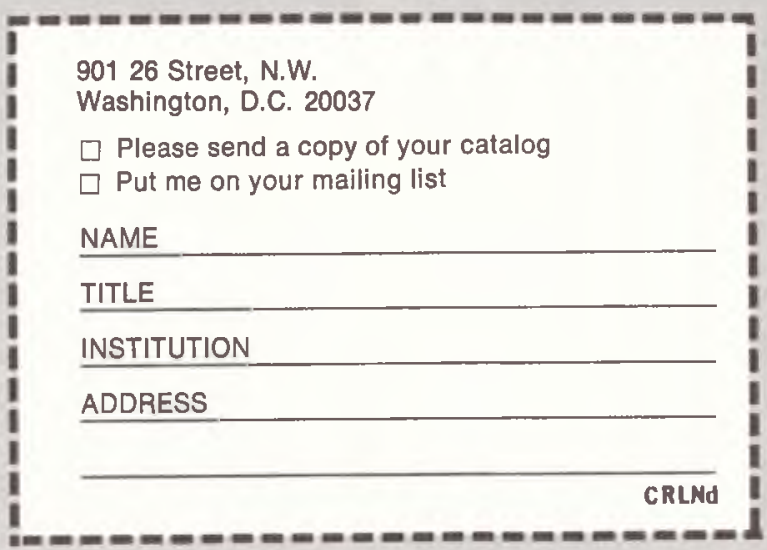




\section{NOW! FROM BAKER \& TAYLOR-LIBRARY OF CONGRESS MARC TAPE CATALOGING AND PROCESSING}

At Baker \& Taylor all titles on MARC tape as supplied unedited by the Library of Congress are now available cataloged and processed and there is no extra charge if LC numbers are not included on vour order.

Catalog cards using Library of Congress classification and subject headings and Unabridged Dewey classification with Library of Congress subject headings (LC/LC and Dewey/LC) provide descriptive cataloging, subject analysis and classification exactly as on MARC tape. Processing materials are computer produced and supplied with your books.

Cataloging and processing from MARC tape offers you a wide variety of call number formats at no extra cost. Here are a few examples of Baker \& Taylor's low cost LC/LC and Dewey/LC processing options:

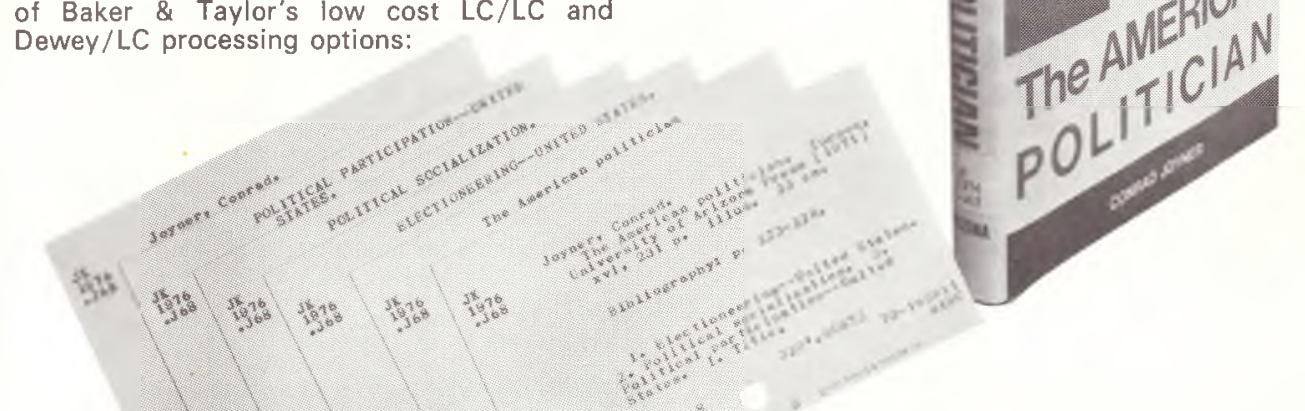

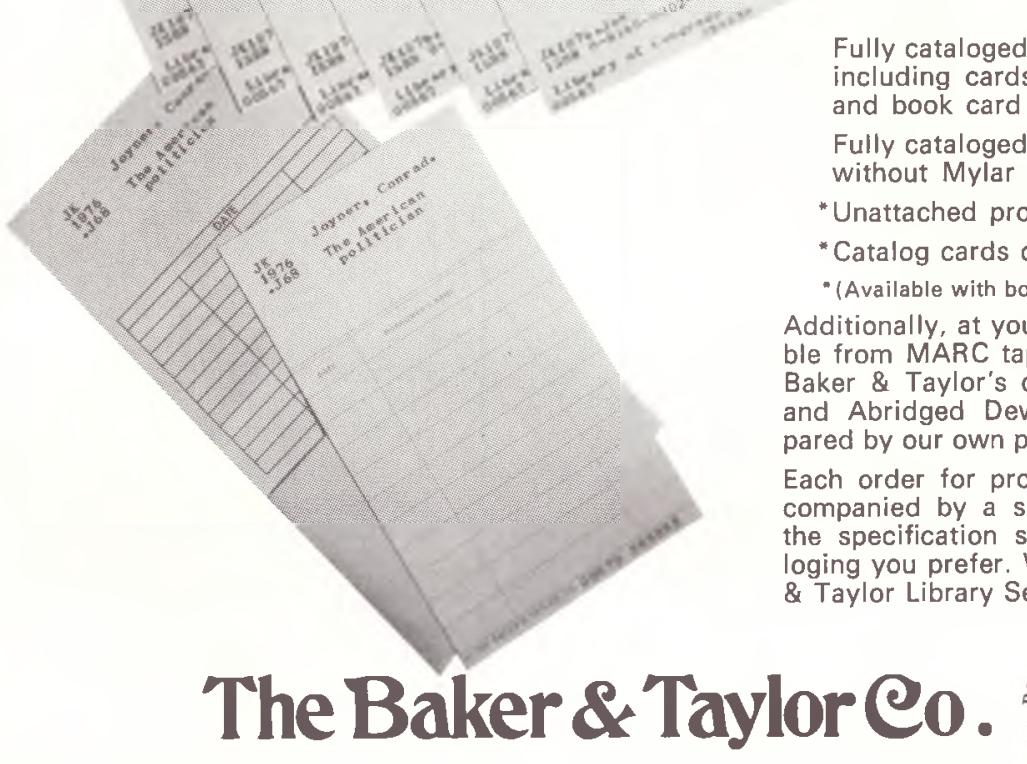

EASTERN DIVISION

SOMERVILLE, NEW JERSEY 08876

50 Kirby Avenue, Tel: 201.722 .8000 N.Y. City Tel: $212 \cdot 227 \cdot 8470$

SOUTHEAST DIVISION
COMMERCE, GEORGIA 30529
Tel: $404-335-5000$
Atlanta Area
Tel: 0 -WX-5555

SOUTHEAST DIVISIO

Atlanta Area Tel: 0-WX-5555

MIDWEST DIVISION

MOMENCE, ILLINOIS 60954

Gladiola Avenue

Tel: $815-472-2444$

Chicago Tel: 312.641-3233

Fully cataloged and processed book, including cards, label, book pocket and book card ...............

Fully cataloged and processed book . Mylar jacket .........65 65 $25 c$

Additionally, at your option, titles not accessible from MARC tape are often available from Baker \& Taylor's computer file of Dewey/LC and Abridged Dewey/Sears cataloging, preEach order for processed books must be accompanied by a specification sheet. Request the specification sheet for the type of cataloging you prefer. Write to your nearest Baker \& Taylor Library Service Center.

Inspection Center for Books and Media: 5820 Wilshire Blvd., Los Angeles, California 90036, Tel: 213-938-2925

Audio Visual Services Division: Box 230, Momence, Illinois 60954, Tel: 815-472-2444 
- ISSUED PROMPTLY ON A BIMONTHLY SCHEDULE

\section{- INDEXES ALL REVIEWS IN OVER 230 PERIODICALS}

This master key to current book commentary gives timely citations to all reviews in over 230 periodicals, including Saturday Review, American Scholar, Library Journal, Choice, Time, Esquire, Booklist, Harper's, Dun's Review, Film Quarterly, Atlantic, New York Review of Books, Journal of Negro History, Horn Book, New York Times, National Review, Philological Quarterly, Kirkus Reviews, and Commonweal.

$B R I$ entries give all the information needed to locate current reviews: author's name, title of book, reviewing publication, and date and page of review. Indexed each year are over 70,000 reviews of more than 35,000 books.

Bimonthly issues of BRI covering 1973 are appearing shortly after the period covered so that subscribers will have information on reviews of books at the vital time they are being considered for purchase by libraries and being discussed by the reading public. To facilitate fast reference, every second issue cumulates the preceding issue.

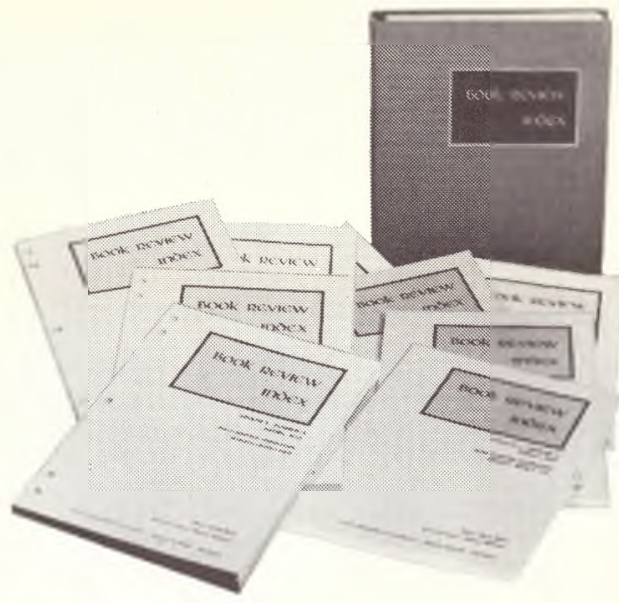

ANNUAL CUMULATIONS

The clothbound cumulation of the periodical issues covering 1972 will be ready in late 1973 ; annual cumulations for 1973 and later will appear shortly after the close of the year covered. In preparation are volumes covering 1971, 1970. and 1969 -the years that $B R I$ was suspended. (Cumulations for 1965, 1966, 1967, and 1968 are all available for immediate shipment.)

Choice: "A basic reference tool which belongs in all libraries."

Booklist: "No other indexing service offers the diversity of Book Review Index. It is recommended for all libraries."

College and Research Libraries: "The great number of periodicals indexed and the inclusion of books reviewed only once make this a practical, useful tool."

\section{SAMPLE ENTRIES}

SARTRE, Jean-Paul - Politics And Literature / TLS - My 4'73 - p502 SARVIS, Betfy - The Abortion Controversy / CC - v90-My 2 '73-p514

SASEK, Miroslav - This Is New York / Inst - v82 - My' 73 - p77

SASEK, Miroslav - This is New York / NYTBR, pt. 2 - My 6 '73-p26

SASEK, Miroslar - This Is San Francisco / NYTBR, pt. 2 - My 6 63 - p26

SASEK, Miroslav - This is Washington, D.C. / BW (WP), pi. 2 - v7

My $13 \cdot 73 \cdot 07$

SASEK, Miroslay - This Is Washington, D.C. / NYTBR, p1. 2 - My 6 '73-p26

SASO, Michael R - Taoism And The Rite Of Cosmic Renewal /

JAS - v32-F'73-p311

SATER, William F . The Heroic Image In Chile / 1J - v98 - Je 1 73 - pl816

SATO, Koji - The Zen Life / TLS - My $18^{\prime} 73$ - p559

SATTLER, Helen Roney - Holiday Gifts, Favors, And Decorations That You Can Make / Inst - v82 - My'73-p78

SATTLER, Helen Roney - Sock Craft / LJ - v98 - My 1573 - pl684

SAUERLANDER, Willibald - Gothic Sculpture In France 1140-1270/ TLS - Ap 13 '73 - p410

SAUNDERS, Rubie - The Franklin Watts Concise Guide To Good Grooming For Boys / LJ - v98 - Ap $15^{\prime} 73$ - p1390

SAVAGE, Arthur W - How To Analyze The Short Story / EJ - v62 Ap 73 - p640

Periodical Issues

1974 subscription.

(six bimonthly issues)

Annual Cumulations

In Preparation

Clothbound annuals for 1973, 1972 . 1971,1970 , and $1969 . \ldots$. \$45 each

Annual Cumulations

In Print

Clothbound annuals for 1965, 1966 , 1967 , and $1968 \ldots \ldots \ldots . \$ 30$ each

All periodical issues and bound volumes sent on 30-day approval. Advance orders have the same no-obligation return privilege. 